This PDF is a selection from an out-of-print volume from the National Bureau of Economic Research

Volume Title: The Effects of Taxation on Capital Accumulation Volume Author/Editor: Martin Feldstein, ed.

Volume Publisher: University of Chicago Press

Volume ISBN: 0-226-24088-6

Volume URL: http://www.nber.org/books/feld87-1

Publication Date: 1987

Chapter Title: The Cash Flow Corporate Income Tax

Chapter Author: Mervyn A. King

Chapter URL: http://www.nber.org/chapters/c11355

Chapter pages in book: (p. 377 - 400) 


\title{
12 The Cash Flow Corporate Income Tax
}

\author{
Mervyn A. King
}

\subsection{Introduction}

Two themes have dominated the debate on corporate tax reform in recent years. First, there is a widespread perception that the cumulative effect of piecemeal changes to the tax system has been to produce major distortions in the pattern of savings and investment. The magnitude of these distortions has recently been documented in King and Fullerton (1984). As a result, the goal of "fiscal neutrality" has attracted a good deal of support. Second, there has been growing concern over the steady erosion of revenues accruing to the government from the corporate sector.

The practical expression of these perceptions has been the elimination of many concessions to investment and savings, particularly at the corporate level. This can be seen most clearly in the major overhaul of the corporate tax system that occurred in the United Kingdom in 1984 (the transition to which was completed in April 1986) and in the U.S. Treasury proposals in both their original November 1984 and subsequent May 1985 versions (henceforth Treasury I and Treasury II respectively). Throughout the postwar period, governments of various persuasions have attempted to stimulate capital formation by offering investment incentives of increasing generosity. These have taken the form of cash grants, credits against tax liabilities, or straightforward tax allowances. But the concessions were introduced in an ad hoc fashion, and by the late 1970s the resulting pattern of incentives was difficult to justify in terms of any rational view of the optimal taxation

Mervyn A. King is Professor of Economics at the London School of Economics and research associate at the National Bureau of Economics. 
of savings. Effective tax rates on investment projects varied enormously from one type of project to another (King and Fullerton 1984). In response to these problems both, the U.S. and U.K. proposals were an attempt to move toward fiscal neutrality by adopting a tax base that could more accurately be described as a measure of economic income. Many of the concessions to investment were eliminated in return for a cut in the corporate tax rate.

The recent debate on tax reform in the United States and the United Kingdom shows that the attempt to return to a comprehensive income tax raises at least as many questions as it answers. The calculation of economic depreciation of an asset, and the measures that are required to index the corporate tax system for inflation, are very difficult to implement in practice. It is appropriate, therefore, to ask whether there is an alternative way to attain the objective of fiscal neutrality without a significant erosion of the tax base.

In this paper we discuss such an alternative. It is called the cash flow corporate income tax. The basic principle behind the idea is that the company is taxed on the net cash flow received from its real business activities. No distinction is made between capital and income in the calculation of a company's tax base. By basing the tax on cash flow the measurement of economic income is removed from the concern of the tax authorities. Such a system achieves fiscal neutrality by harmonizing investment incentives on a common basis, namely immediate expensing of all investment expenditures. The incentive to invest with such a tax is greater than would be the case under either Treasury I or Treasury II plans, and also under the new U.K. corporate tax system. The motivation for the cash flow tax is to apply the principles of a consumption or expenditure tax to the corporate sector. The idea is not new and can be traced back at least as far as Brown (1948); its practical implementation was discussed in King (1975), Kay and King (1978), Meade Committee (1978), and Aaron and Galper (1985).

There are three main parts to this chapter. First, section 12.2 describes the principles of a cash flow corporate income tax and explains how it would work. The second part of the chapter analyzes the effects of the corporate cash flow tax on the firm's choice of financial policy and its debt-equity mix, and also upon the cost of capital facing the company when making investment decisions. Financial policy is analyzed in section 12.3, and section 12.4 discusses the impact of the tax on the cost of capital to a firm and the effective tax rate on an investment project. Attention will be focused on three issues that have received rather little attention in previous discussions. First, the nature of any problems that arise from the interaction between a cash flow tax at the corporate level and an income tax at the personal level. Second, the incidence of the corporate cash flow tax depends upon the marginal 
source of finance to the representative company, and the identification of the marginal source of funds requires a general equilibrium model of the corporate sector's capital structure. Third, the corporate cash flow tax illustrates vividly the potential for dynamic inconsistency in government fiscal policy.

The final chapter, section 12.5 , discusses some of the more practical problems that would arise if the cash flow corporate income tax were to be implemented. These include (i) transitional arrangements, (ii) international considerations, and (iii) the likely revenue consequences of a change in the tax base.

\subsection{A Cash Flow Corporate Income Tax}

Recent research has shown that the corporate income tax introduces a number of distortions into savings and investment decisions. To eliminate these, one might either move to a more neutral tax base or eliminate the separate tax on corporations altogether. The latter course would have many attractions were it not for the following two considerations. First, a corporate income tax exists already, and to abolish it would be to yield windfall capital gains to the current owners of corporate equity. There is truth in the well-known adage that "an old tax is a good tax." Second, in the absence of a tax on corporate income it may be difficult to tax the capital income received by foreign investors in domestic companies or domestic subsidiaries of foreign corporations.

The cash flow corporate income tax represents an attempt to design a tax that is neutral with respect to both financial and investment decisions, and at the same time continues to yield the government positive revenue from past investments, from profits in excess of the normal rate of return, and also from activities financed by overseas investors. It is attractive for a further reason, namely that the base of the tax requires no adjustment for inflation, and hence that the complicated indexation provisions for depreciation, for example, required under alternative corporate tax systems are unnecessary with a cash flow tax. This is because the tax is based on the sources and uses of funds statement and not on the profit and loss account. The tax eliminates the necessity of calculating "economic profit." Hence there is no need to construct a true measure of depreciation or to make any adjustment for the effects of inflation.

The basic principle of the tax is to levy a charge on the net cash flow to the company resulting from its real economic activities. The tax base can be measured as the difference between the receipts from sales of goods and services and the purchases of all real goods and services required in the production process, including purchases of capital goods. At the same time the tax base would disallow any deduction for the 
financing of the investment. Hence there would be no deductibility of either interest payments or dividends. The major departures from the present system would be the granting of immediate expensing $(100 \%$ first-year depreciation allowances) to all forms of investment (but given this there would be no need for an investment tax credit), and interest payments would no longer qualify as a deduction for the purposes of the corporate income tax. Moreover, there would be no room for dividend deduction schemes of the type proposed in the recent Treasury plans. In practice, there would need to be transitional arrangements to prevent both undue hardship and also tax avoidance during the transition from the current system to a new cash flow tax base. These, and other practical questions to which satisfactory answers must be provided before the tax could be implemented, are discussed further in section 12.5 below.

The nature of double-entry bookkeeping means that the total sources of funds to a company are identical to its total uses of funds. An important implication of this identity is that the base of the cash flow tax can be described in either of two ways. The first is the difference between sales and purchases: the net cash flow from real economic activity. The second is the difference between dividends paid to shareholders and issues of new shares.

The former may be described as the corporate cash flow base and the latter as the net equity distributions base. To see the relationship between the two, examine the corporate sources and uses of funds shown in table 12.1. In terms of the notation of table 1 , the two tax bases, denoted by $T B_{1}$ and $T B_{2}$ respectively, are given by the equations

$$
\begin{gathered}
T B_{1}=R-I \\
T B_{2}=D-S .
\end{gathered}
$$

Table 12.1

Corporate Sources and Uses of Funds

\begin{tabular}{llll}
\hline Sources & Uses \\
\hline$R$ & $\begin{array}{l}\text { Receipts from sales of goods and } \\
\text { services less purchases of labour, } \\
\text { raw materials and services }\end{array}$ & $I$ & $\begin{array}{l}\text { Investment expenditure (gross } \\
\text { investment less receipts from } \\
\text { sales of assets) }\end{array}$ \\
$B \quad \begin{array}{l}\text { Borrowing (new issues of debt } \\
\text { less repayments of old debt) }\end{array}$ & $P$ & $\begin{array}{l}\text { Interest payments (net of interest } \\
\text { received) }\end{array}$ \\
$S \quad \begin{array}{l}\text { New share issues (less share } \\
\text { repurchases), including net sales } \\
\text { of shares in other companies. }\end{array}$ & $D$ & $\begin{array}{l}\text { Dividends paid (less dividends } \\
\text { received) }\end{array}$ \\
\hline
\end{tabular}

Accounting Identity $R+B+S=I+P+D+T$ 
From the flow of funds identity it follows that

$$
T B_{2}+T \equiv T B_{1}+(B-P) .
$$

The two differences between the corporate cash flow and net equity distributions bases can be seen to be the following. First, because taxes paid enter into the sources and uses of funds statement, the corporate cash flow basis is a measure of the tax base on a tax-inclusive basis, whereas the definition in terms of net equity distributions is measured on a tax-exclusive basis. If the tax rate on the corporate cash flow base were $50 \%$, then this would be equivalent to a tax rate of $100 \%$ on the net equity distributions base. Second, to the extent that a company earns real profits from transactions in financial assets (other than equities), then the corporate cash flow base would not include those profits. Only if the net equity distributions base were used would such profits be taxed. This is a major consideration for financial institutions, such as banks, which derive their earnings primarily from the provision of financial services for which no direct charge is levied but which are reflected in differences between borrowing and lending rates. The same phenomenon can be observed in the national accounts, in which the real economic profits of the financial sector are recorded as negative. This is because the national accounts use real transactions to measure profits and ignore profits on financial transactions. If no profit is made on such financial transactions, then the present value of interest payments equals the present value of net borrowing, and, over time, given a constant tax rate, the corporate cash flow base and the net equity distributions base are identical. This is likely to be approximately true for major industrial corporations, and as far as nonfinancial activity is concerned the two bases have identical economic effects. It will prove convenient to analyze these effects in terms of the corporate cash flow base because this may more readily be compared with the existing base and with reforms that have been proposed. The two bases could be made identically equal by modifying the corporate cash flow base to include the difference between net new borrowing and net interest payments. In other words, interest deductibility would continue, but new borrowing would constitute a taxable receipt. It is clear from equation (3) that the amended corporate cash flow base must in all circumstances be identical to the net equity distributions base except for the fact that the former is tax-inclusive and the latter tax-exclusive. The tax-exclusive rate, $t_{2}$, is related to the tax-inclusive rate, $t_{1}$, by the equation

$$
t_{2}=\frac{t_{1}}{1-t_{1}}
$$


Apart from the treatment of profits on financial transactions, there is a difference between the corporate cash flow base and the net equity distributions base in terms of the transitional problems that might arise in attempting to move from the present system toward a cash flow tax. Some of these practical issues are taken up in section 12.5. But we turn first to an analysis of the long-run effects of the cash flow corporate income tax on the optimal financial and investment policy of a company once the tax is in place, and we contrast these effects with those that would follow from the adoption of alternative tax bases such as those proposed in the recent Treasury plans.

\subsection{Financial Policy and the Debt-Equity Mix}

It is well known that the current U.S. corporate income tax affords a tax advantage to debt rather than equity, because of the deductibility of interest payments, and discriminates in favor of internal equity finance (retained earnings) and against the issue of new shares. The rationale for this pattern of incentives is unclear. A thriving equity market, particularly for new risk capital, provides one of the main routes by which household savings are channeled into corporate investment. It is perhaps not surprising, therefore, that there have been frequent proposals to relieve the double taxation of dividends inherent in the present system. The most recent were the Treasury I and Treasury II plans, both of which advocated a partial dividend deduction. In this section we contrast the incentives to use debt and equity that are implied by a cash flow tax on the one hand, and alternative reforms, such as the Treasury dividend deduction proposal, on the other.

To do this we first analyze the effects of different taxes on a company's choice of financial policy in general, and then apply the results to particular systems of company taxation. Both personal and corporate taxes are relevant to the choice of debt-equity mix. Two personal tax rates are distinguished here, the marginal income tax rate of investors, denoted by $m$, and the effective tax rate on accrued capital gains, denoted by $z$. Differences in tax rates among investors will be discussed below. Because capital gains tax is charged on gains only when they are realized, the effective tax rate on accrued gains is significantly lower than the nominal statutory rate. In addition, it has been argued that the ability to exploit the short-term-long-term gains distinction further erodes the effective rate and may possibly lead to a negative effective tax rate. For our purposes we note solely that the value of $z$ is bounded above by the statutory rate.

Three corporate tax variables are relevant to the analysis. These are the rate of tax on taxable profits that would be paid if no profits were distributed, denoted by $\tau$, the opportunity cost of retained earnings in 
terms of gross (i.e. pre-income tax) dividends, foregone, denoted by $\hat{\theta}$, and the fraction of interest payments that are tax-deductible, denoted by $\beta$. The value of $\hat{\theta}$ measures the rate at which cash in the company's hands may be transformed into cash in the hands of the stockholders (Feldstein 1970; King 1971, 1977). Under the current U.S. tax system a transfer of a dollar from the company to the shareholders produces a gross dividend of one dollar. Hence $\hat{\theta}$ equals unity. With alternative tax systems, such as a dividend deduction scheme or the imputation system employed in most EEC countries, the value of $\hat{\theta}$ generally exceeds unity to reflect the credit given to the shareholders, explicitly or implicitly, for taxes already paid at the corporate level. To evaluate $\hat{\theta}$ under different tax regimes it is helpful to define the total tax liability of the company, denoted by $T$, as the total taxes paid by the company and stockholders together less the income tax on dividends and capital gains tax paid by the stockholders. From this definition

$$
T=\tau Y+\frac{(1-\hat{\theta})}{\hat{\theta}} \cdot G
$$

where $Y$ is taxable corporate income and $G$ is total gross dividends. From the definition of $\hat{\theta}$ the extra taxes (minus the credits) that result from a distribution are $(1-\hat{\theta}) / \hat{\theta}$ per unit of gross dividends.

We may now contrast (5) with the formulas that describe the operation of various tax regimes. Under the current U.S. system the corporate tax liability is simply

$$
T=c Y
$$

where $c$ is the rate of corporate income tax.

Equating coefficients in (5) and (6) confirms that $\tau=c$ and $\hat{\theta}=1.0$. Under the imputation system used widely in Europe, part of the corporate tax liability is credited against the shareholders' income tax liability on dividends. In effect, the company is deemed to have paid income tax on behalf of the shareholders at some rate, which is described as the rate of imputation (denoted by $s$ ). Hence

$$
T=c Y-s G
$$

This implies that

$$
\begin{aligned}
\tau & =c \\
\hat{\theta} & =\frac{1}{1-s} .
\end{aligned}
$$

The gross dividend received by the stockholder is equal to the cash dividend payment made by the company grossed up by the rate of imputation. 
The Treasury plans proposed that a fraction of dividends be deductible for the purposes of the corporate income tax. Denote the fraction of dividends that are deductible by $\lambda$. In Treasury I $\lambda$ was 0.5 , and in Treasury II $\lambda$ was 0.1 . With a dividend deduction the corporate tax liability becomes

$$
T=c(Y-\lambda G) .
$$

Hence

$$
\begin{aligned}
\tau & =c \\
\hat{\theta} & =\frac{1}{1-c \lambda} .
\end{aligned}
$$

From this it can be seen that in terms of economic effects the dividend deduction proposed is equivalent to an imputation system with a rate of imputation equal to the product of the corporate tax rate and the fraction of dividends that is deductible. There are two points to note about this. First, a change in the corporate tax rate will automatically change the effective rate of imputation unless a compensating change in $\lambda$ is made. Second, the effective rate of imputation is very sensitive to the value of $\lambda$. For example, in the Treasury I plan, with a corporate tax rate of $33 \%$ and $\lambda=0.5$, the effective imputation rate is $16.5 \%$. Under the Treasury II proposals, with the same corporate tax rate but $\lambda=0.1$, the effective imputation rate is only $3.3 \%$. Moreover, both values are low when compared with imputation rates in Europe. In the United Kingdom, for example, the rate of imputation is $30 \%$ (from April 1986, 29\%).

The cash flow tax is a variant of the classical system of corporate income taxation, which is that currently used in the United States. The value of $\hat{\theta}$ in both cases is unity. The major difference between the cash flow tax and the present system lies in the treatment of debt finance. With a cash flow tax, interest payments are not deductible for corporate income tax purposes (or, equivalently, borrowing is a taxable receipt). Debt finance would be less attractive than at present.

The incentive to use different sources of finance can be seen from the following pairwise comparisons between debt finance, retained earnings, and new share issues. In each case we compare the net of tax income that could be distributed out of one unit of corporate profits corresponding to the differing methods of remunerating investors implied by the different sources of finance. The results are simply stated below; derivations may be found in King $(1977,1986)$. At this stage we ignore indexation of the tax system.

(i) Debt finance is preferred to retained earnings if

$$
(1-m)>(1-z)(1-\beta \tau) \text {. }
$$


(ii) Debt finance is preferred to new share issues if

$$
1>\hat{\theta}(1-\beta \tau) \text {. }
$$

(iii) Retained earnings are preferred to new share issues if

$$
(1-z)>(1-m) \hat{\theta} \text {. }
$$

From these equations it is clear that with a cash flow corporate income tax there would be fiscal neutrality between debt finance and new equity issues (from 12). Retained earnings would be the most attractive source of finance for taxable investors, and financial policy would be a matter of complete indifference for tax-exempt investors such as pension funds. Neutrality could be achieved for all investors by either taxing capital gains at income tax rates or adopting a consumption tax treatment of household capital income. Under the current U.S. tax code, debt finance dominates new share issues, and for almost all investors debt finance also dominates retained earnings. With the dividend deduction proposal of the Treasury plans, the condition for debt finance to be more attractive than new equity issues is (from 12)

$$
\beta>\lambda \text {. }
$$

Only if the rate at which dividends may be deducted exceeds the proportion of interest payments that is deductible will new share issues dominate debt finance. The Treasury plan envisaged retaining full deductibility of interest $(\beta=1)$ and values for $\lambda$ of 0.5 and 0.1 for Treasury I and Treasury II respectively. Under these proposals, debt finance would retain its tax advantage. Moreover, the effective imputation rate would be independent of the tax rate of the investor, and so neutrality between internal and external equity finance would be impossible to achieve.

It has long been argued in the United States that partial integration of the corporate and personal income taxes, as far as dividends are concerned, would alleviate much of the discrimination against equity inherent in the current system. But partial measures of this type do not deal adequately with the substantial spread among marginal investor tax rates. Indeed, the imputation system in Britain has been criticized by the employers' federation (CBI 1985, p. 69) on precisely these grounds.

It is clear that the 1986 system . . . will for a majority of shareholders, provide either a strong bias in favour of distribution or indifference as between distribution and retention . . . the 1986 system will in time produce broadly two types of company:

a) Typical quoted companies with mainly institutional or basic rate taxpayer shareholders, which will make very full dividend payments ... . 
b) Companies with largely top rate taxpayer shareholders, making minimal distributions.

The Exchequer will of course lose substantially as a result of this.

The conclusion reached by the CBI's Tax Reform Working Party was that Britain should adopt a cash flow corporation tax.

\subsection{The Cost of Capital}

The principle aim of the cash flow corporate income tax is to avoid distortion of investment decisions by ensuring that the cost of capital is independent of the particular investment project under consideration. By the cost of capital is meant here the pretax rate of return net of depreciation that is required on a project in order to call forth the funds needed to finance it. It is the financial rather than the user cost of capital (the latter includes also the return necessary to finance depreciation of the asset).

To illustrate the effect of the cash flow tax, and of other possible reforms, on the cost of capital, we consider the simple case in which true economic depreciation occurs at the nonstochastic exponential rate $\delta$. With this assumption a firm's cost of capital, denoted by $c$, is given by the following expression:

$$
c=\frac{\left(1-f_{1} A_{D}-f_{2} \tau-f_{3} g\right)}{(1-\tau)}\{\rho+\delta-\pi\}-\delta
$$

where $f_{1}=$ proportion of investment expenditure that qualifies for ordinary depreciation allowances.

$\mathrm{f}_{2}=$ proportion of investment expenditure that receives cash flow tax treatment (i.e. immediate expensing)

$\mathrm{f}_{3} \quad=$ proportion of investment expenditure that qualifies for a cash grant or investment tax credit.

$\mathrm{A}_{D} \quad=$ present value of tax savings from ordinary depreciation allowances.

g $=$ rate of cash grant or equivalent rate of investment tax credit

$\rho \quad=$ rate at which company discounts net of corporate tax cash flows

$\delta=$ exponential rate of true economic depreciation

$\pi \quad=$ rate of increase of price of investment goods.

Equation (15) states that the required pretax real rate of return on a project, adjusted for depreciation, is equal to the real rate of return that must be offered to the suppliers of finance grossed up by the corporate tax rate and multiplied by the effective price of a new asset. The latter is the market price less the present value of the tax allowances 
for depreciation and other investment incentives. Indexation of depreciation allowances lowers the effective price of capital goods. For simplicity of exposition, (15) omits corporate wealth taxes and the taxation of the inflationary component of inventory profits. A treatment of these issues may be found in King and Fullerton (1984) and King (1986).

The value of the rate at which the company discounts net of corporate tax cash flows, denoted by $\rho$, depends upon the source of finance used for the project and upon the identity of the marginal investor. It depends also upon the indexation provisions of the tax code. In a partial equilibrium model in which all investors have identical tax rates, the following are the relevant expressions for the corporate discount rate for each source of finance (see Appendix for the derivations). The nominal interest rate in economy is denoted by $i$.

(i) debt finance

(ii) new share issues

$$
\begin{aligned}
& \rho=i(1-\beta \tau)+\beta \tau \pi I_{i} \\
& \rho=i / \hat{\theta}+\left[\frac{m I_{i}-z I_{z}}{(1-m) \hat{\theta}}\right] \pi \\
& \rho=i\left[\frac{1-m}{1-z}\right]+\left[\frac{m I_{i}-z I_{z}}{1-z}\right] \pi
\end{aligned}
$$

where $I_{i}$ and $I_{z}$ are dummy variables that take the value unity when interest payments and capital gains, respectively, are fully indexed for tax purposes and are zero in the absence of indexation.

Partial equilibrium expressions for the cost of capital corresponding to the different sources of finance can be derived by substituting the appropriate values for the corporate discount rate into equation (15). In a general equilibrium model, however, we would expect that the discount rates would be equal for all sources of finance employed by the firm, and the difficulty in constructing convincing general equilibrium models is to imagine plausible mechanisms by which the marginal discount rates are brought into equality. One such model is the Miller equilibrium (Miller 1977), in which investors face constraints on short sales of all assets. In this equilibrium the constraints are binding on all investors except those who are indifferent between equity and debt finance as far as taxes are concerned. The marginal investor is the unconstrained investor, and the company, which itself faces no constraints on its financial policy, is indifferent at the margin between debt and equity finance. For the marginal investor the cost of equity finance is equal to that of debt finance, and the income tax rate of the marginal investor is such that the discount rate given by equations (16) and (18) are equal. Hence from the tax point of view this is equivalent to calculating the cost of capital as if the firm financed marginal projects by debt finance. In such an equilibrium it is easy to evaluate the effects 
of different tax regimes on the cost of capital and hence on the optimal level of investment. In the case of the cash flow corporate income tax, interest payments are not deductible for tax purposes $(\beta=0)$ and there are no indexation provisions. The corporate discount rate is from (16) simply the nominal interest rate. In addition, all investment expenditure can be immediately expensed $\left(f_{2}=1, f_{1}=f_{3}=0\right)$, and hence from equation (15) the cost of capital is given by the following expression

$$
c=i-\pi=r
$$

In other words, the cost of capital is equal to the real interest rate. The rates of tax, both at the personal and the corporate level, have no effect on the relationship between the market interest rate and the required rate of return on investment projects. The decision rule that a firm uses in the presence of taxes is identical to the rule that it would use in the absence of taxes. The existence of a cash flow corporate income tax does not distort the investment decision.

The reason for this result is clear. With immediate expensing the government is effectively subsidizing investment at exactly the same rate as it taxes profits. The cost of any project is reduced by the same fraction as the future benefits will be reduced when taxes are levied (assuming a constant tax rate). Given that both the benefits and costs of the project are reduced in the same proportion, then, provided the discount rate is unaffected by the tax rate, any project that was accepted in the absence of a tax would be accepted with the tax. This result assumes that there are always sufficient taxable profits for the tax allowances to be used to offset current tax liabilities. Alternatively the tax system must provide for complete loss offset by allowing tax losses to be carried forward marked up by the nominal interest rate. With this tax system the government becomes a partner in the firm, albeit a sleeping partner (see also King 1975). It makes a contribution on new investment at the same rate as it shares in the profits of the enterprise. On new marginal investment projects the system is effectively a zero tax. But on intramarginal projects and on investment made prior to the introduction of the cash flow corporate income tax, the tax acts as a capital levy on the owners of corporate assets.

One of the great advantages of the cash flow tax is that the cost of capital can be seen to be independent of the inflation rate without any need to introduce complicated indexation provisions. The same cannot be said of any tax that attempts to measure "economic profits." The only long-run problem with the cash flow tax is that there is a possible time inconsistency involved in government policy. Given that the tax has no disincentive effects on investment but yields revenue from the intramarginal projects, the government would have an apparent incentive to announce that the tax rate would remain at its present level but 
in the future to go back on its word and to raise the rate of tax. In this way it would appear to be able to raise additional revenue from lump sum taxes. If this increase in the tax rate were anticipated, then of course the tax would no longer be a lump sum tax and investment decisions would be affected. In practice, the United Kingdom had a very similar tax system in force from 1973 until 1984, and no attempt was in fact made to raise the rate of tax. Moreover, this was a period in which the administration alternated between the two main political parties. It is possible that concern about their reputation led governments to forego the short-run benefits of retrospective taxation.

If we maintain the assumption of a Miller equilibrium and turn to the effects of other possible tax systems, then, with interest deductibility, the only system that is neutral is one that offers no accelerated depreciation but grants ordinary depreciation allowances at rates corresponding to true economic depreciation. These must be fully indexed for inflation. Such was the aim of Treasury I. Since economic depreciation is notoriously difficult to measure, such a system could only be expected to approximate the requirements for neutrality. Moreover, in the discussions that followed the publication of Treasury $I$, indexation found much less favor with Congress than with the authors of the Treasury plans. This experience appears to support the view of the Meade Committee (1978), which recommended a cash flow corporate income tax over a tax based on comprehensive income partly on the grounds that the calculations required for a measure of "economic profit" were complex and difficult to administer.

If we relax the assumption of a Miller equilibrium, then the discount rate for the company will reflect the tax treatment of dividends and personal tax rates on both dividends and capital gains. There is no really satisfactory general equilibrium model of corporate financial behavior outside of the simple Miller equilibrium, but if one were constructed, the marginal cost of capital would be a weighted average of the costs of capital for the different sources of finance. The difficulty is to identify the weights that would be used. Fewer distortions would be expected from a tax system that discriminated less between the different sources of finance, and, as we saw in section 12.3, the cash flow corporate income tax scored well on this point.

The problem with the simple Miller equilibrium is that it contains a clearly counterfactual prediction, namely that, except for the marginal investor, all other investors would be completely specialized in either debt or equity securities. One simple alternative is to calculate a weighted average cost of capital, using as weights the average proportion of investment financed from different sources. Such calculations were made for the then existing tax system in the comparative study of King and Fullerton (1984). To contrast the effect of a cash flow tax on the 
cost of capital with that of the Treasury plans, and to compare both possible reforms with the present system, we present below updated estimates of the effective marginal tax rate on capital income as calculated in the King and Fullerton study. To do this, the posttax real rate of return to the investor corresponding to the pretax rate of return on a project (the cost of capital as defined here) is computed for each investor. Denote this posttax rate of return by $s$. The effective marginal tax rate is now defined as

$$
t=\frac{c-s}{c}
$$

Table 12.2 shows effective marginal tax rates for the United Kingdom and the United States under several alternative tax regimes. For the United Kingdom the figures are shown for the pre-1984 position, the new 1986 regime, and the situation that would result if the 1986 system were converted into a cash flow corporation tax. In the case of the United States, the rates are shown for the 1984 starting point, the two Treasury plans (I and II), and the hypothetical case of Treasury I amended to include a pure cash flow corporate income tax but with all the personal tax changes intact. The inflation rate assumed in the calculations is $5 \%$ per annum.

It is clear that even without adopting a consumption tax at the personal level, the cash flow corporate income tax eliminates many of the more extreme distortions that are evident in the current system.

\subsection{Problems of Implementation}

\subsubsection{Transitional Arrangements}

Two sets of issues arise when designing a suitable transition to the new tax base. The first consists of the problems that arise from the application of the new tax base. The second is the question of how far the expected consequences of the old base are continued after the introduction of the new tax. The second is the easier to deal with and so is considered first.

On the date when the new base comes into force, companies have a stock of depreciation allowances that they expect to be able to carry forward and deduct (in a predetermined time profile) against future taxable profits. There seems no good reason to deny companies the right to continue to deduct depreciation allowances on past investment. To abolish the existing stock of depreciation allowances would be akin to a windfall profits tax in proportion to past investment-not a happy precedent to set. Nevertheless, the Hall-Rabushka (1983) plan did imply such an effect. Moreover, unless the date on which the tax becomes 


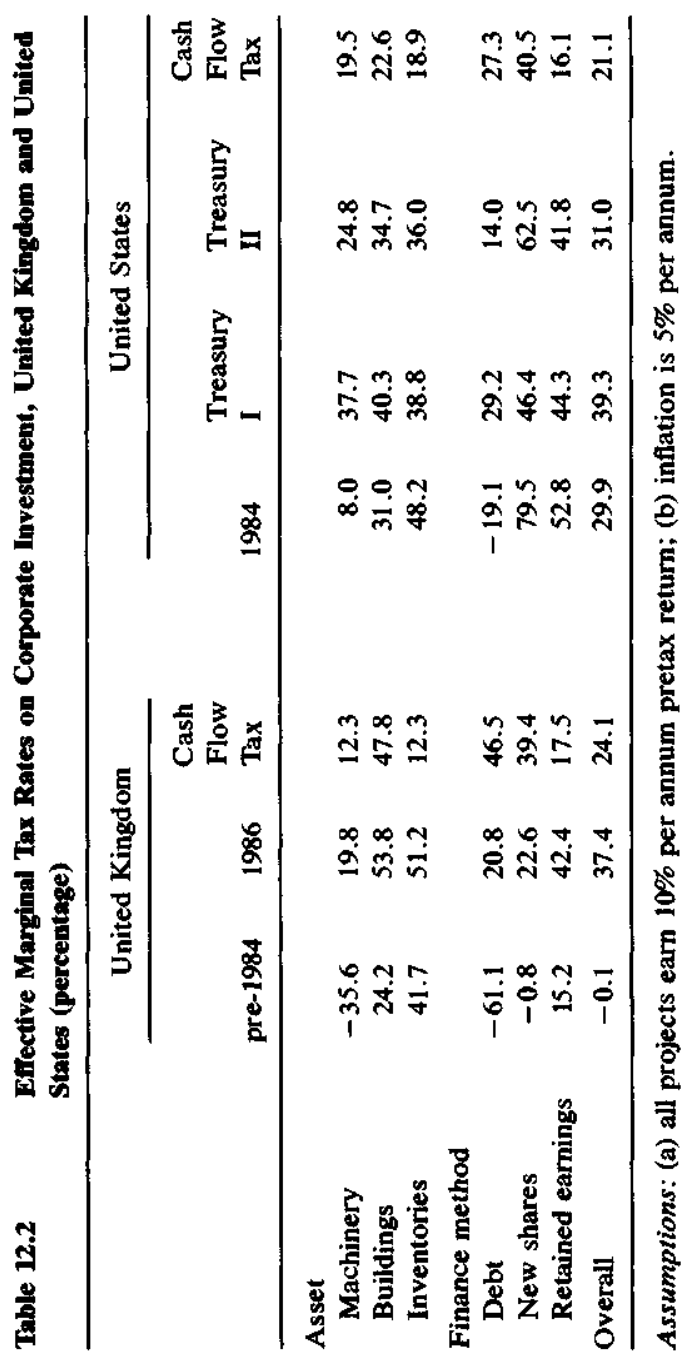


effective can be made retrospective, anticipation of the change would lead to a collapse in investment in the period between announcement and the date when the enabling legislation was passed. In the United Kingdom, it is possible for the government to announce that, conditional upon the proposed legislation receiving Parliamentary approval within a certain period, the new tax would be effective from the date of announcement. But in the U.S. context this seems less plausible.

Similar arguments apply to other forms of "losses" that companies had expected to be able to carry forward to offset against future profits. Continuation of such loss carryforwards is straightforward under the real basis, but with the net dividends basis the simplicity of the tax would be reduced because net distributions constitute a tax-exclusive base whereas loss carryforwards are inherited from a tax-inclusive regime. To retain simplicity, the loss carryforwards could be converted into a stock of tax credits (or, more generally, a flow of tax credits over time) on the transition date.

The other set of problems results from the implications of the new base, although their nature differs as between the real and net distributions bases. With the former, the main problem is that debt interest payments are no longer tax-deductible. For new debt finance this raises no problems, but for borrowing incurred before the announcement of the new base there is a retrospective charge on the cost of servicing the debt, which in some, perhaps many, cases could cause acute financial distress for highly geared companies. One solution is simply to phase out interest deductibility by reducing the proportion of interest payments that are deductible (the value of $\beta$ in section 12.3) gradually over a period of, say 5 to 10 years, from unity to zero. As far as the net distributions basis is concerned there is a more serious transitional problem. Unless the new basis becomes effective on the date of announcement, companies would have a strong incentive to raise their debt-equity ratios by borrowing and paying high dividends before the transition date, and then to issue new equity in order to repay the loans and reduce dividends after the transition date in order to repay the loans and restore their debt-equity ratios to normal levels. Similar incentives existed in the United Kingdom during the major corporate tax reforms of 1965 and 1973, and, although revenue losses occurred, the problem was regarded as manageable. Nevertheless, antiavoidance provisions would be necessary because the scope for avoidance using purely financial transactions is large.

\subsubsection{Long-run Administrative Problems}

In this section we describe some of the administrative problems that the tax would present on a permanent basis. The first concerns the treatment of borrowing. Under the corporate cash flow basis, only real 
transactions are taken into account and profits made on financial transactions are exempt from tax. This does not appear to be a satisfactory method of taxing financial institutions. If the cash flow base were adopted, then a separate tax would be required for such institutions. Alternatively, under the net equity distributions basis, which does tax the profits on financial transactions, rules would be required to prevent companies from issuing debt at artificially high interest rates. Such payments would be exempt from corporate tax and would be a method of returning profits to the shareholders free of tax. Of course, this problem exists under the current tax with interest deductibility. Current rules would need to be carried over. Some of the other problems that exist with the current corporate tax system would remain with the new tax. There would still need to be a distinction between corporate and personal expenditure in order to levy the appropriate amounts of personal income tax on benefits provided by the company. Under the net equity distributions basis, new rules would be required to determine the amount of dividends that enter the tax base when some part of the dividend was paid in kind. Shareholder benefits of all types (for example, reductions in the price of the company's products when sold to its shareholders) come under this heading.

A second area of potential problems concerns the phenomenon of tax exhaustion. This is the situation in which the company has no current taxable income and is accumulating tax losses that will be carried forward. A question that arises is how far it is thought to be acceptable for companies to trade such tax losses among themselves. Under the existing tax systems in both the United States and the United Kingdom, trading of tax losses takes place with leasing. The U.S. authorities have taken a much harder line on this than their U.K. counterparts, although it is not easy to see why companies should be prevented from offsetting the unintended effects of an asymmetric tax system. The limiting case would be to create a market in corporate tax losses. Failing that, companies could be allowed to carry forward losses marked up by the market interest rate, which would leave the incentive to invest unaffected by the asymmetric treatment of positive and negative taxable profits. In the absence of such a provision, leasing would be the market solution under the corporate cash flow basis. Under the net equity distributions basis, a rather different set of companies would be tax-exhausted. These would be firms that had made substantial issues of new shares. Such a company could reduce its tax loss by borrowing in order to purchase shares in other resident companies, and in the absence of loss carryforward with interest would have an incentive so to do.

Although these problems are rather different under the two alternative bases, they do not seem to be more serious under one than under 
the other. The cash flow basis perhaps has a cosmetic advantage in appearing more familiar. But the net equity distributions basis would enable the revenue authorities to adopt a common fiscal year for all companies without the need for companies to change their own accounting periods.

The treatment of overseas investment and profits remitted from abroad also raises some important questions. With a cash flow corporation tax there is no obvious reason to grant credit for foreign taxes paid. This is because the government, as has been argued above, is a partner in the firm's equity. If the foreign corporate tax rate is at least as great as the domestic tax rate, then the government would receive no return on its investment in the firm's activities overseas. But if foreign tax credit is denied, then the firm receives a return on its own share of the investment equal to the net of foreign tax rate return on the investment, i.e. the return to society on this investment overseas. One problem with the denial of foreign tax credit is that it would be difficult to impute that part of foreign taxes attributable to investment made after the introduction of the cash flow tax and that part attributable to investment made before the change in the system. Hence an alternative means of achieving the same objective would be to deny investment relief for overseas investment. Under the cash flow base this would be straightforward in that the investment made overseas would not qualify for immediate expensing. With the net equity distributions base, an additional tax would be levied on overseas investment at the appropriate tax-inclusive rate. Where the foreign tax rate was below the domestic corporate tax rate, then the additional charge (or reduction in allowances for investment) would be scaled down in proportion to the ratio of the two tax rates. It is interesting to note that for 12 years (197284) the U.K. government did allow companies both to receive $100 \%$ first-year allowances on overseas investment made by branches and also to receive credit for foreign taxes paid. This was effectively a subsidy to overseas investment. Nevertheless, it seems unlikely that this position could be maintained if there were a permanent shift to a cash flow corporation tax.

\subsubsection{Revenue Implications of the Cash Flow Tax}

At first sight it might appear that a tax which offers such generous investment incentives would require a higher tax rate to raise the same amounts of revenue as under the current corporate tax system. A little reflection, however, demonstrates that this is not the case. The new tax base would imply the abolition of investment tax credits and grants, and also of deductions for interest payments on new loans and for dividends. A full-scale calculation of the tax rate that would be required to raise the same amount of revenue would involve a general equilib- 
rium analysis of the incentive effects of the new tax. This beyond our scope here. Instead we report some partial equilibrium estimates of the rate that will be required assuming no behavioral responses.

In the United Kingdom the Meade Committee (1978) found that over the period 1964-74 the required tax rate would have been $35 \%$ under the cash flow base and $34 \%$ under the net equity distributions base. These figures compare with the actual tax rate of between $40 \%$ and $45 \%$ over this period. Subsequently, the 1982 Green Paper on Corporation Tax claimed that the revenue-neutral rate of tax for the net equity distributions basis for the period 1973-81 would have been about $200 \%$ on a tax-exclusive basis. But Edwards (1982) showed that this calculation incorrectly attributed Advance Corporation Tax payments to the total corporate tax liability, when it is in fact more appropriately seen as a deduction at source of income tax at the basic rate on dividends. Making this correction, he found that the revenue-neutral rate assuming unchanged behavior was $47 \%$ for the net equity distributions base, as compared to the actual rate of $52 \%$ that prevailed throughout this period. Using individual company data, Mayer (1982) found that for the period $1965-76$ the average rate required for revenue neutrality would have been $52 \%$ under the cash flow base and $42 \%$ under the net equity distributions base. All of these calculations show that there is no reason to suppose that the tax rate would have to rise if the base were switched to a corporate cash flow base.

Similar calculations for the United States by Aaron and Galper (1985) found that for the net equity distributions base a tax rate of $33 \%$ would have raised the same revenue as was in fact raised during the period 1981-83 with a tax rate of $46 \%$. Again there seems reason to suppose that a switch to a cash flow base would lead to problems of revenue loss, provided adequate transitional arrangements were made.

\subsection{Conclusions}

Recent proposals for tax reform have raised the question of how easy it is to measure economic depreciation for the corporate sector. The effects of any proposed reform on investment will depend upon their impact on the cost of capital, which in turn depends upon how the allowances for depreciation built into the tax code relate to underlying true economic depreciation. The proposals for economic depreciation embodied in Treasury I entailed complete indexation of the corporate tax. It appears that these proposals are unlikely to be implemented. It is worth considering, therefore, whether there is any alternative tax base for which the cost of capital is independent of the inflation rate and which eliminates some of the existing distortions between different types of investment. One possible candidate is the cash flow corpo- 
ration tax. Two versions of this tax were analyzed in this chapter: the cash flow base on real transactions and the net equity distributions base. From the analysis of their effects on investment incentives, and the administration arrangements that would be required for their implementation, it seems that the cash flow base is worthy of serious consideration in the current debate on reform of corporate taxation.

\section{Appendix}

In this appendix we derive expressions for the nominal discount rate that companies will use to compare net of corporate income tax cash flows in different periods. The novel feature is the explicit modeling of indexation of the tax system. The discount rate depends upon the source of finance that the firm uses, and can be thought of as the required net of tax return that the company must earn in order to be able to persuade investors to supply finance to the company. The corporate discount rate is denoted by $\rho$.

\section{(i) Debt Finance}

This is the simplest case in which the nominal discount rate is simply the effective net of tax interest rate at which a company can borrow. This is the market interest rate, $i$, less the tax savings for interest payments granted at the corporate level. A fraction $\beta$ of interest payments are deductible against the corporate tax rate, and if such payments are indexed for tax purposes, then the deduction applies only to real interest payments. Hence

$$
\begin{aligned}
\rho & =i-\beta \tau\left(i-\pi I_{i}\right) \\
& =i(1-\beta \tau)+\beta \tau \pi I_{i}
\end{aligned}
$$

where $I_{i}$ is an indexation dummy variable that takes the value unity when interest payments are indexed for tax purposes and zero otherwise.

\section{(ii) New Share Issues}

Where new share issues are the optimal source of finance, the company will distribute all of its profits as dividends and finance investment by the sale of new equity. The return that the company earns net of corporate tax (the value of $\rho$ ) must be such that the net of tax dividend that it can finance is equal to the investor's opportunity cost of funds, which in turn is equal to the net of tax interest rate that the investor can earn on alternative investments. For an investor whose marginal income tax rate is $m$, this condition implies that

$$
i-m\left(i-\pi I_{i}\right)=(1-m) \hat{\theta} \rho+z \pi I_{z}
$$


where $I_{z}$ is a dummy variable that takes the value unity when capital gains are indexed for tax purposes and is zero otherwise.

The RHS of (A.2) is the net of tax dividend plus the reduction in capital gains tax resulting from the real capital loss that arises when all profits are distributed as dividends and capital gains tax is indexed for inflation. This tax benefit disappears if either inflation is zero or capital gains tax is unindexed.

Rearranging (A.2) yields

$$
\rho=\frac{i}{\hat{\theta}}+\frac{\left(m I_{i}-z I_{2}\right) \pi}{(1-m) \hat{\theta}}
$$

(iii) Retained Earnings

In the case of retained earnings the nominal return earned by the company, net of the investor's additional capital gains tax liability generated by the return, must equal the investor's opportunity cost of funds. Hence

$$
i-m\left(\mathrm{i}-\pi I_{i}\right)=\rho-z\left(\rho-\pi I_{z}\right)
$$

Rearranging terms gives

$$
\rho=i\left[\frac{1-m}{1-z}\right]+\left[\frac{m I_{i}-z I_{z}}{1-z}\right] \pi
$$

\section{References}

Aaron, H. J., and H. Galper. 1985. Assessing tax reform. Washington, D.C.: Brookings Institution.

Brown, E. C. 1948. Business-income taxation and investment incentives. In Income, employment and public policy; Essays in honor of Alvin H. Hansen. New York: W. W. Norton.

CBI. 1985. Tax-time for change. London: Confederation of British Industry.

Edward, J. 1982. The Green Paper on corporation tax: A review article. Fiscal Studies 3: 102-13.

Feldstein, M. S. 1970. Corporate taxation and dividend behaviour. Review of Economic Studies 37: 57-72.

Hall, R. E. and Rabushka, A. 1983. Low tax, simple tax, flat tax. New York: McGraw-Hill.

Kay, J. A., and M. A. King. 1978. The British tax system. Oxford: Oxford University Press. (4th edition 1986.)

King, M. A. 1971. Corporate taxation and dividend behaviour-a Comment. Review of Economic Studies 38: 377-80.

- 1975. Current policy problems in business taxation. In Bedrifts Beskatning. Bergen: Norwegian School of Economics.

. 1977. Public policy and the corporation. London: Chapman and Hall. 
1986. Business taxation, finance and investment. Mimeo, London School of Economics.

King, M. A., and D. Fullerton. 1984. The taxation of income from capital. Chicago: University of Chicago Press.

Mayer, C. 1982. The structure of corporation tax in the UK. Fiscal Studies 3: 121-41.

Meade Committee. 1978. The structure and reform of direct taxation. London: Allen \& Unwin.

Miller, M. H. 1977. Debt and taxes. Journal of Finance 32: 261-75.

U.S. Treasury. 1984. Tax reform for fairness, growth and simplicity. Washington, D.C.: U.S. Government Printing Office.

United States. 1985. The president's tax proposals for fairness, growth and simplicity. Washington, D.C.: U.S. Government Printing Office.

\section{Comment Daniel Feenberg}

King's thoughtful and precise analysis shows that a cash flow tax could offer important advantages over the U.S. corporate income tax. A tax on cash flow is inflation-neutral, it allows a required rate of return equal to the interest rate, and it abstracts from the impossible tasks of valuing accrued income and depreciation. While some biases in the valuation of accruals may be attributed to bureaucratic timidity or political interference, the real difficulty of defining income should not be underestimated. A tax levied at a high rate on the difference between two unobserved but highly correlated flows severely strains the tax administration machinery.' By removing the unobserved components from the tax base, the cash flow tax reduces the scope for tax avoidance and therefore the need for regulations.

The most difficult and controversial sections of current tax law regulate the treatment of asset transactions. Under the cash flow tax, these are particularly simple. Neither asset valuation nor basis affects (total) tax payments. Revenue authorities could be indifferent among possible characterizations of such transactions as sales, mergers, reorganizations, or acquisitions, because all of them would have identical tax consequence. In contrast, under an income tax the form and substance of a transaction often imply different tax liabilities. There would, however, be a powerful incentive for noncorporate capital to move to the

Daniel Feenberg is a research associate of the National Bureall of Economic Research.

1. There is a large industry devoted to disputing estimates of corporate income and expenses. The local property tax generates a similar government revenue but does relatively little for the legal and accounting professions. The income tax is levied on a very small base (taxable income), and errors in the estimates of gross income and expenses are carried into that base dollar for dollar. Therefore small percentage errors are magnified. Similar percentage errors in a real estate assessment would generate much smaller differences in property tax liability. 
corporate sector, because a deduction for the full purchase price would accrue to the corporation, while the individual seller would take as income only the sale price less his basis. ${ }^{2}$ Even if cash flow type rules were extended to the personal sector, in the presence of graduated rates there is a prodigious scope for gaming the tax system by the mechanical application of cash flow rules to transactions among taxpayers in different brackets.

In King's proposal the cash flow tax applies approximately current income tax rates to the cash flow minus real investment of the corporation. No deductions for interest or dividends are allowed. Equilibrium in the capital market implies that the present value of the tax on new investment will have an expected value of zero. Discounted at the interest rate, the cash flow generated will just equal the price of capital goods. Since the government takes the same share of gross cash flow as it provides in initial subsidy, the government's share must also have a market value of zero. Nevertheless, the tax does generate revenues from the existing capital in the corporate sector, on which the government takes a share of cash flow but only allows depreciation deductions.

King argues that it is necessary to continue to tax old capital in order to avoid windfall gains to the current owners of corporate equity. This is far from apparent to me. If the investment incentive aspect of the cash flow tax is effective, then enough additional capital will be brought forth to equate the marginal product of capital to the interest rate. Old capital still subject to tax must fall in value relative equally productive capital placed in service under the new and more generous tax regime. This would impose a loss on current owners of capital.

If the cash flow tax were implemented in a small corner of the world, then there would be little effect expected on the aftertax interest rate. The existing equilibrium, which relates the marginal product of capital $F_{k}$, the corporate tax rate $t$ and the interest rate $p$,

$$
F_{k}(1-t)=p
$$

would be disturbed by new investment that is effectively tax-free until

$$
F^{\prime}{ }_{k}=p \text {. }
$$

But the present value of capital still subject to the old rules must fall by $t$ to equilibrate the market for old and new capital. The hypothesized windfall gain to the owners of old capital is possible if investment fails to respond to the higher after-tax rate of return. Yet in that case the investment subsidy aspect of the CFT is also ineffective. This may

2. King allows unused depreciation allowances to be carried forward into the new tax regime, but disallows all existing basis. This would be the source of some horizontal inequity. 
surprise some readers: if the tax on old capital is not increased, how can the owners have a justified complaint against the government? The answer depends on the constitutional structure of society, and stands apart from the question of the loss itself, which is unambiguous.

Certainly the history of corporate taxes in the United States since 1945 has been one of declining rates on new capital essentially without change in the treatment of existing capital. Therefore the cash flow tax may be the end of a road we are already well along. Current investment may well be inhibited by the expectation that capital placed in service today will be competing with still more lightly taxed capital available to firms tomorrow. In that case failure to adopt the expected incentives will generate windfall gains for owners of existing capital. But there can be no presumption that maintaining current rules only for existing capital will prevent windfall gains and losses. Indeed, in the example above, windfall gains and losses can be avoided only by a commitment to tax all capital under the same rules, even if those rules change through time. 